Article

\title{
Environmentally-Related Cherry Root Cambial Plasticity
}

\author{
Mirjana Ljubojević ${ }^{1, *(\mathbb{D}}$, Ivana Maksimović ${ }^{1}$ (D) Branislava Lalić ${ }^{1}$, Ljiljana Dekić $^{2}$, \\ Tijana Narandžić ${ }^{1}$, Nenad Magazin ${ }^{1}$, Jovana Dulić ${ }^{1}$, Maja Miodragovićc ${ }^{1}$, Goran Barać ${ }^{1}$ \\ and Vladislav Ognjanov ${ }^{1}$ \\ 1 Faculty of Agriculture, University of Novi Sad, Trg Dositeja Obradovića 8, 21000 Novi Sad, Serbia; \\ ivanam@polj.uns.ac.rs (I.M.); lalic.branislava@gmail.com (B.L.); tijana.narandzic@uns.ac.rs (T.N.); \\ nmagazin@polj.uns.ac.rs (N.M.); jovana.dulic@polj.uns.ac.rs (J.D.); maja.miodragovic@polj.uns.ac.rs (M.M.); \\ goranb@polj.uns.ac.rs (G.B.); vognjanov@polj.uns.ac.rs (V.O.) \\ 2 Republic Hydrometeorological Service of Serbia, Kneza Višeslava 66, 11000 Belgrade, Serbia; \\ lj.dekic@gmail.com \\ * Correspondence: ikrasevm@polj.uns.ac.rs; Tel.: +381-21-4853-373; Fax: +381-21-450-123
}

Received: 10 August 2018; Accepted: 14 September 2018; Published: 17 September 2018

\begin{abstract}
The general aim of this research was to determine whether the cherry root cambium possesses similar water-stress adaptation abilities as the scion. Specifically, this study aimed to determine whether there is a shift in root xylem structure due to precipitation fluctuations and temperature increase during the growing season in two cherry species. Oblačinska sour cherry and European ground cherry roots with secondary structure were anatomically surveyed in detail, and correlated with meteorological conditions occurring during the vegetation when the roots were formed. Under environmental signals, both investigated species altered their radial root growth imprinting stops and starts in a cambial activity that resulted in the occurrence of intra-annual false growth rings. Changing environmental conditions triggered the shifts of large and small vessels throughout the false growth rings, but their size seemed to be mainly genetically controlled. Taking into consideration all the above, genotypes with moderate vessel lumen area-lesser or around $1200 \mu^{2}$ in the inner zone, as well as no greater than $1500 \mu \mathrm{m}^{2}$ in the outer zone-are presumed to be both size-controlling and stable upon the drought events. Thus, further field trials will be focused on the SV2 European ground cherry genotype, and OV13, OV32, and OV34 Oblačinska sour cherry genotypes.
\end{abstract}

Keywords: adaptability; cambial activity; P. cerasus; P. fruticosa; phloem; precipitation; temperature; vessel size; xylem

\section{Introduction}

Fruit production across the world relies on inter-specific grafted trees, rather than intra-specific seedlings, which has enabled the expansion of growing areas, including various soil and environmental conditions. Due to comprehensive scion and rootstock breeding, sweet cherry is ranked in sixth place according to total temperate fruit production [1]. Sweet cherries are cultivated in more than 40 countries worldwide, with the production increases from year to year, due to high consumer demands [2]. Intensive fruit production is inconceivable without size-controlling rootstocks characterized by high compatibility and productivity [3]. One rootstock is generally considered as desirable if it raises early bearing, highly productive compact fruit trees suitable for pedestrian orchards. If those planned and selected genetically inherited characteristics are present, rootstock gains prompt popularity among producers and it spreads across the world very rapidly. Marketing and sales pressure of large quantities from nursery production can cause low-adaptive rootstock expansion, regardless of environmental restrictions. In rootstock selection strategies, the focus is on phenotypically (assumed mainly to be 
genetically inherited) described properties such as good anchorage, good radial and axial hydraulic conductivity, and water use efficiency. Atmospheric impact is often neglected as it is considered that the root system is not so exposed and susceptible to the influence of meteorological conditions, as the scion is [4]. Previous models developed based on cross-sections of the anatomical parameters of one- and two-year-old roots and rootstock stems of leading cherry rootstocks and selections proved to be reliable for size-controlling capacity prediction within species and interspecific hybrids of the genus Prunus $[3,5,6]$. The same autochthonous cherry germplasm has shown annual adjustments towards the seasons. Approaching autumn, the majority of the investigated genotypes increased their vessel numbers and decreased vessel sizes to provide mechanical support, in contrast to spring wood, when the vessel size was greater and was a function of abundant water conductance [3,5]. Under dry summer conditions, this is of great importance due to the fact that narrow vessels in the stem are generally more resistant to drought-induced embolism than wide vessels of the same stem [4,7-9]. Climate scenarios for the Balkan region predict an increase in average surface temperatures from 2.2 to $5.1^{\circ} \mathrm{C}$ for the period $2080-2100$. For the same period, the models predict that precipitation over land might vary between $-4 \%$ and $-27 \%$ [10]. Summer drought in Balkan region is prominent, with climate changes prevailing in the last decade being characterized by unevenly distributed precipitation and high temperatures. Dehydration (long dry periods during summer months) and rehydration (short lasting but heavy rainfalls) cycles during vegetation have become a common phenomenon that limits fruit growing [3]. Persistent, long dry intervals of up to 2-3 weeks in the period of xylem formation directly influence and leave imprints on its major properties, since division, expansion, and maturation of xylem cells happens over several days to a few weeks [11,12]. Short conduit formation span and very variable environmental conditions require high temporal plasticity for the individual plant's successful water uptake, overall functioning, and survival [11].

Analyzing the possible autochthonous cherry rootstock candidates' rapid adaptability of earlywood to overcome the last years' embolized large vessels by the production of new functional ones, Ljubojević et al. [3] suggested the potential for cherry cambial and xylem plasticity. Due to proposed xylem plasticity, those genotypes are assumed to be better adapted to drought and embolism caused by freezing/thawing and hydration/dehydration cycles. Those aboveground stem xylem adjustments are generally well known and recognized over the many deciduous and coniferous trees and herbaceous perennial taxa, due to dendro-chronology and herb-chronology investigations [13-16], but to the authors' best knowledge, there has been no such report on root cambial and xylem environmentally driven plasticity [17], especially in fruit rootstocks. According to Brunner et al. [17], roots are capable of withstanding drought events due to various morphological and physiological adjustments, but there is still not enough knowledge regarding root anatomical responses to drought, as they are marginally mentioned in reviews and often avoided in research.

Considering results from previous studies on stems, the general aim of this research was to examine whether the cherry root cambium possess the similar water-stress adaptation ability as the scion cambium does. The specific aim of this study was to assess whether there is a shift in root xylem structure due to precipitation fluctuations and temperature increase during the growing season in two contrasting root systems-deep and vertically oriented in P. fruticosa versus shallow in P. cerasus 'Oblačinska'.

\section{Experiments}

\subsection{Research Aim Background}

Cherry rootstock breeding at the Faculty of Agriculture, Novi Sad, Serbia is an ongoing project focused on vast biodiversity of genus Prunus, its collection, evaluation and conservation both in situ and ex situ. During 2010, the root systems of more than 40 cherry genotypes belonging to Prunus fruticosa (Pall.) and Prunus cerasus (L.) ecovar. Oblačinska were morphologically and anatomically evaluated for selection purposes. Although the sampling methodology was identical throughout the survey, 
some roots of the same age showed more than one growth ring-like formation across the wood sections, characteristic only for stems. The most prominent genotypes according to previously defined selection goals were subsequently vegetatively propagated in a fogging irrigation system, wherein newly grown annual roots with secondary structures showed no ring-like formations (Figure 1a). According to further analysis, roots derived from those vegetatively propagated plants formed far smaller vessel lumen areas that gradually decreased with xylem maturation [3]. The occurrence of growth ring-like formations in secondary roots collected from in vivo mother plants (Figure 1b), and their absence in the roots of clonally propagated plants of the same age and genotypes, required an in-depth analysis of the precipitation and temperature regime during the time of formation, in order to access the heat and drought stress impact on plant development. In the absence of meteorological measurements on locations of interest, hourly temperature and precipitation data during the very dry 2010 vegetation period, were obtained from the ERA 5 database [18] for the locations of Fruška gora, Dešilovo, and Prokuplje. ERA5-ECMWF ReAnalysis is a climate reanalysis dataset, covering the period from 1950 to the present, with a temporal resolution of one hour, and a horizontal resolution of $30 \mathrm{~km}$.

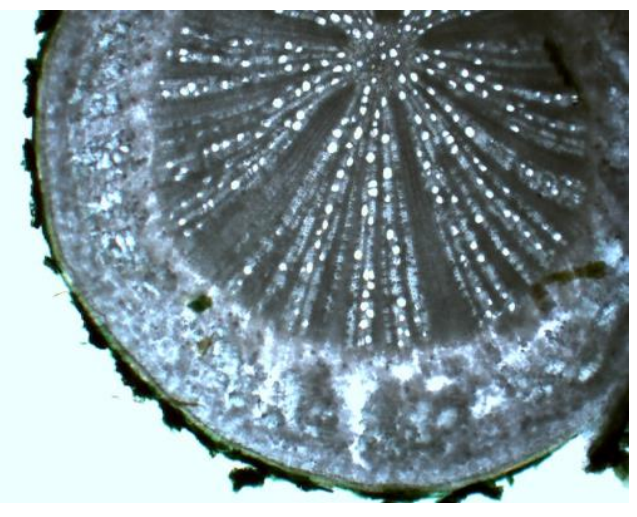

(a)

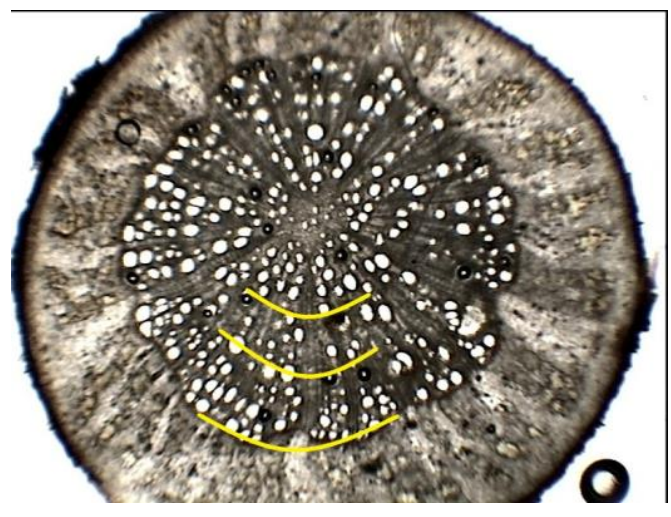

(b)

Figure 1. Light micrographs of 'Oblačinska' sour cherry-OV31 roots with secondary structure on a magnification of $40 \times$. (a) Typical semi-ring porous xylem structure in the secondary root formed in the fogging irrigation system (b) Occurrence of growth ring-like xylem formations in the secondary roots formed in the natural habitat and collected from in vivo mother plants.

The analysis was conducted from March (beginning of root vegetation) to August (time of sampling). The weather data series included monthly precipitation (PPT), number of days with amount of precipitation less than $0.1 \mathrm{~mm}$ - extremely dry days $\left(\mathrm{PPT}_{0}\right)$, duration of dry period (dry days) - number of days with precipitation less than $5 \mathrm{~mm}\left(\mathrm{PPT}_{<5 \mathrm{~mm}}\right)$, average monthly temperatures $\left(\mathrm{T}_{\mathrm{m}}\right)$, and number of very hot days $\left(\mathrm{T}_{\max }>30^{\circ} \mathrm{C}\right)$.

\subsection{Study Site and Plant Material}

European ground cherry (P. fruticosa) and Oblačinska sour cherry (P. cerasus) two-year-old roots with secondary structure were sampled from mother trees at three localities at the end of August of 2010 (Table 1). Basically 'two-year-old root' means that in the previous year, the given root (considered as fine, hairy root) had primary structure, while the secondary structure, which is the object of this research, formed during the next vegetation stage. The primary structure had become less prominent, almost neglectable, and limited to a very small area at the very center of the section, due to secondary thickening pressure. Thus, cross-sections and investigated secondary wood (xylem) and cortex (phloem) characteristics were considered as annual. 
Table 1. Sampling locations coordinates and altitudes for investigated cherry species.

\begin{tabular}{ccccc}
\hline Species & Locality & Longitude & Latitude & Altitude \\
\hline European ground cherry & Fruška gora & $19^{\circ} 55^{\prime} 01^{\prime \prime} \mathrm{E}$ & $45^{\circ} 09^{\prime} 39^{\prime \prime} \mathrm{N}$ & $327 \mathrm{~m}$ \\
Oblačinska sour cherry & Dešilovo & $21^{\circ} 37^{\prime} 35^{\prime \prime} \mathrm{E}$ & $4317^{\prime} 34^{\prime \prime} \mathrm{N}$ & $398 \mathrm{~m}$ \\
Oblačinska sour cherry & Prokuplje & $21^{\circ} 32^{\prime} 54^{\prime \prime} \mathrm{E}$ & $4313^{\prime} 46^{\prime \prime} \mathrm{N}$ & $274 \mathrm{~m}$ \\
\hline
\end{tabular}

All three sampling sites were characterized as hilly slopes with altitudes between 274 and $398 \mathrm{~m}$ (Table 1). The first site, where European ground cherry genotypes (marked as SV2 and SV4) were sampled, is located in the northern part of Serbia, in Fruška gora Mountain. The climate of this area is characterized as temperate continental with a mean annual temperature of $11.1^{\circ} \mathrm{C}$, and an average annual precipitation sum of $624 \mathrm{~mm}$ [16]. The other two sites, where Oblačinska sour cherry genotypes were sampled, are located in the southern part of Serbia, in Municipalities Merošina, village Dešilovo (genotypes marked as OV11-OV18), and Prokuplje (genotypes labeled as OV31-OV34). According to the 'Spatial plan of the Prokuplje Municipality' [19], the average sum of the annual rainfall is only $541 \mathrm{~mm}$, which makes it semi-arid. In accordance with this study, from 1994-2004, the average precipitation was reduced in comparison to the previous period by 50 to $80 \mathrm{~mm}$. The mean annual temperature for the period $1981-2010$ was $11.9^{\circ} \mathrm{C}$. A similar study conducted for the Merošina Municipality [20] stated that this region is exposed to dry summer winds, which in addition to uneven precipitation, create drought events. The mean annual temperature is $10.1{ }^{\circ} \mathrm{C}$, while the mean annual precipitation is slightly above $600 \mathrm{~mm}$.

\subsection{Anatomical Characteristics}

Sampling methodology and subsequent root preservation, cross-section preparation, and investigation was conducted as described by Zorić et al. [21] and Ljubojević et al. [3,5]. Five skeletal woody roots (with secondary structure) from in situ mother plants were taken approximately $10 \mathrm{~cm}$ from the branching point from different sides of the root system. The plant material was fixed and preserved in $60 \%$ ethanol, with the addition of $10 \%$ glycerin. Cross-sections were obtained using a hand microtome and subsequently examined and measured by light microscope and the image analyzing system Motic Images Plus. The measurements employed included cross-section and xylem characteristics on four radial segments, $90^{\circ}$ apart, on each root cross-section. The anatomical measurements included cross-section radius, cross-section area $\left(\mathrm{mm}^{2}\right)$, surface areas, and proportions of the secondary cortex - phloem and secondary wood — xylem with its main characteristics—vessel number and size.

Since root thickness enabled the analysis of a greater number of visual fields on one radius, for measurement purposes, secondary wood was divided into three zones: inner (the oldest formed in early spring), middle, and outer (the youngest formed in August), in genotypes from the sites Fruška gora and Prokuplje, while in genotypes from the site Dešilovo, thickness enabled division in only two zones-inner and outer.

\section{Results}

\subsection{Root Anatomical Characteristics of Investigated Cherry Genotypes}

A cross-section analysis of roots with secondary structure revealed intra- and interspecific differences among the investigated cherry accessions. European ground cherry genotypes were characterized with greater cross-sectional areas, with values $27.9 \pm 3.70 \mathrm{~mm}^{2}$ in SV2 (Figure 2a) and $33.4 \pm 10.1 \mathrm{~mm}^{2}$ in SV4 (Figure $2 \mathrm{~b}$ ), in which secondary wood and secondary cortex, as well as periderm percentage, differed. A larger proportion of secondary wood was recorded in SV2 $(52.5 \pm 3.03 \%)$, while SV4 was characterized by a larger portion of the secondary cortex $(47.8 \pm 12.1 \%)$. Periderm average values of the periderm proportions were $3.70 \pm 1.66 \%$ in SV2, and $12.7 \pm 1.41 \%$ in SV4. Oblačinska sour cherry genotypes from the locality of Dešilovo were characterized with a far smaller average cross-section area (from $7.24 \pm 3.81 \mathrm{~mm}^{2}$ in OV18 to $17.5 \pm 3.75 \mathrm{~mm}^{2}$ in OV14), 
in which secondary wood, secondary cortex, periderm percentage, and especially wood/cortex ratio were more consistent (Table 2). Oblačinska sour cherry genotypes from the locality of Prokuplje were characterized with greater cross-sections (from $10.9 \pm 5.40 \mathrm{~mm}^{2}$ in OV31 to $20.8 \pm 10.4 \mathrm{~mm}^{2}$ in OV34), but they showed the same consistency in the above-mentioned structural parameters.

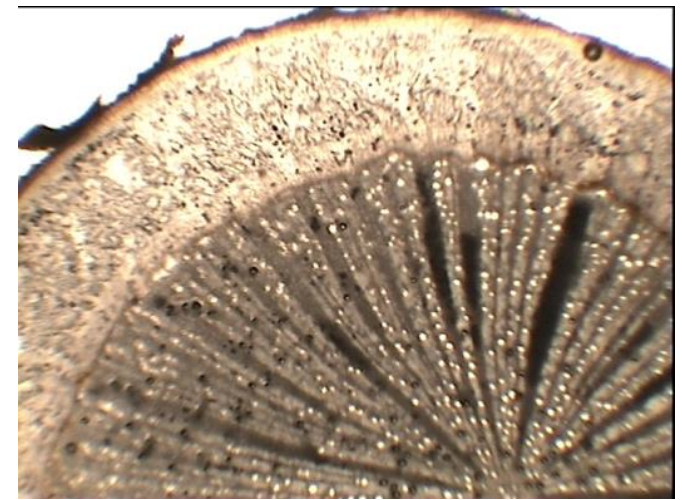

(a)

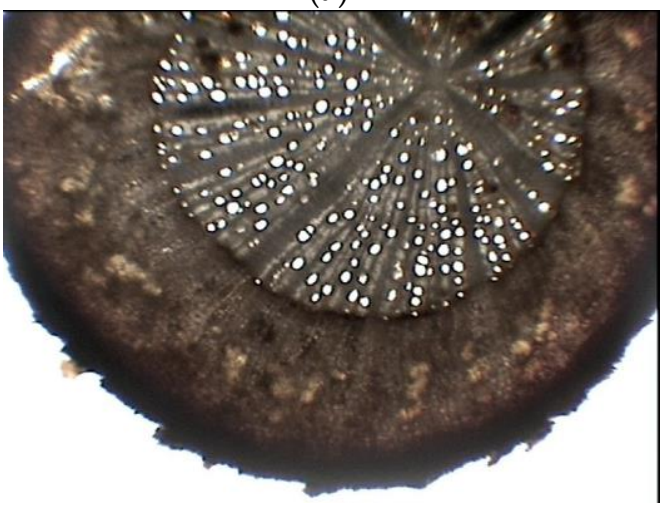

(c)

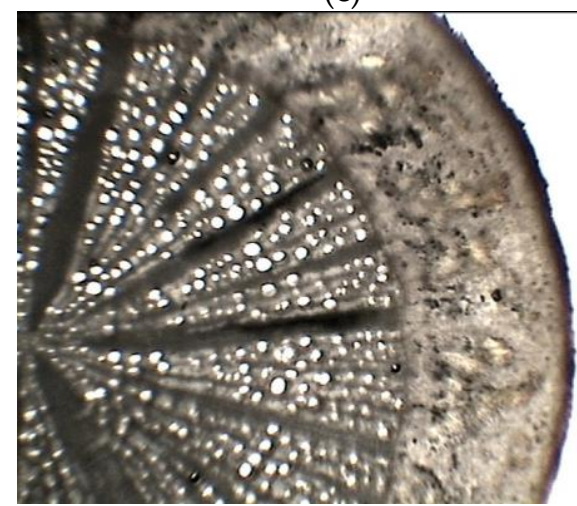

(e)

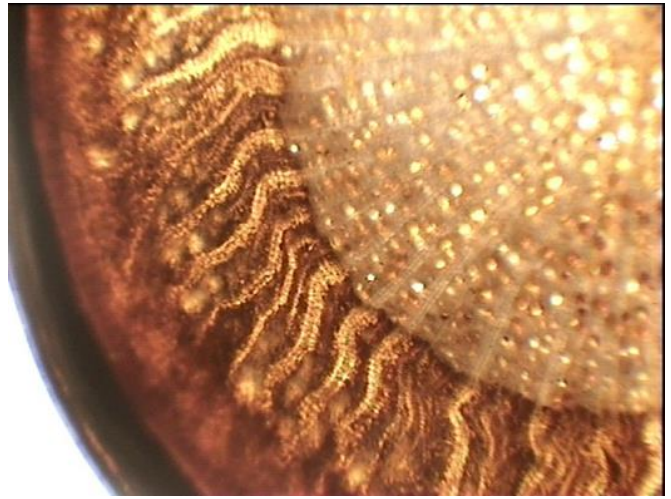

(b)

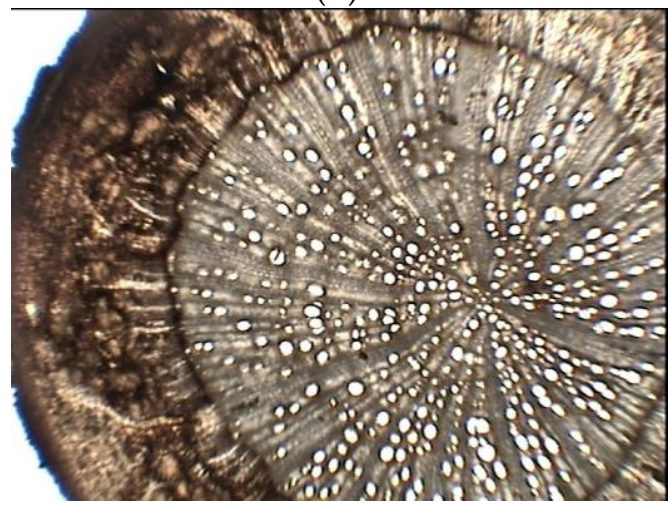

(d)

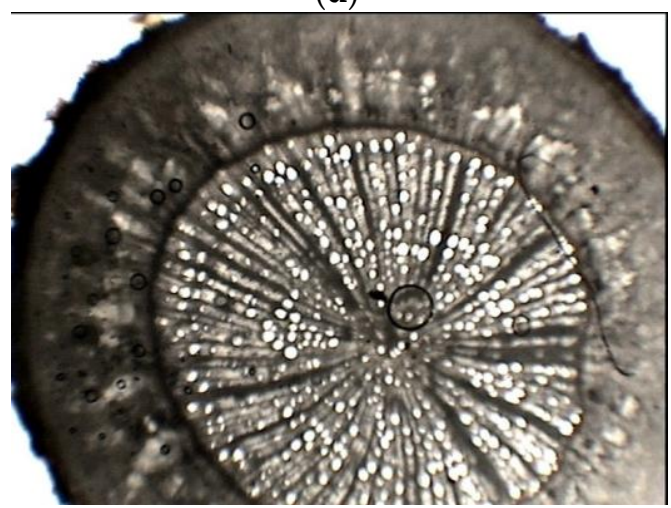

(f)

Figure 2. Light micrographs of skeletal root cross-sections of investigated cherry species on a magnification $40 \times$ (a) European ground cherry ( . fruticosa) -SV2 root with secondary structure; (b) European ground cherry (P. fruticosa)-SV4 root with secondary structure; (c) P. cerasus 'Oblačinska'-OV13 root with secondary structure; (d) P. cerasus 'Oblačinska'-OV17 root with secondary structure; (e) P. cerasus 'Oblačinska'-OV32 root with secondary structure and (f) P. cerasus 'Oblačinska'-OV33 root with secondary structure. 
Table 2. Anatomical characteristics of roots with secondary structure.

\begin{tabular}{|c|c|c|c|c|c|c|}
\hline Genotype & $\begin{array}{l}\text { Cross-Section } \\
\text { Radius (mm) }\end{array}$ & $\begin{array}{l}\text { Cross-Section Area } \\
\left(\mathrm{mm}^{2}\right)\end{array}$ & $\begin{array}{l}\text { Secondary Wood } \\
\text { Area }(\%)\end{array}$ & $\begin{array}{l}\text { Secondary Cortex } \\
\text { Area }(\%)\end{array}$ & Wood/Cortex Ratio & Periderm Area (\%) \\
\hline \multicolumn{7}{|c|}{ European ground cherry-Locality Fruška gora } \\
\hline SV2 & $2.98^{b}$ & $27.9 \pm 3.70^{\mathrm{a}, \mathrm{b}}$ & $52.5 \pm 3.03^{a}$ & $43.8 \pm 3.90^{c}$ & $1.21 \pm 0.17^{\mathrm{a}}$ & $3.70 \pm 1.66^{\mathrm{d}}$ \\
\hline SV4 & $3.24^{\mathrm{a}}$ & $33.4 \pm 10.1^{\mathrm{a}}$ & $39.5 \pm 13.4^{b, c, d}$ & $47.8 \pm 12.1^{b, c}$ & $0.89 \pm 0.51^{b}$ & $12.7 \pm 1.41^{\mathrm{a}}$ \\
\hline \multicolumn{7}{|c|}{ Oblačinska sour cherry-Locality Dešilovo } \\
\hline OV11 & $1.99^{\mathrm{d}}$ & $12.7 \pm 4.18^{\mathrm{c}-\mathrm{f}}$ & $35.4 \pm 5.16^{\mathrm{b}-\mathrm{e}}$ & $60.1 \pm 7.84^{\mathrm{a}}$ & $0.61 \pm 0.15^{\mathrm{c}, \mathrm{d}, \mathrm{e}}$ & $4.32 \pm 3.07^{\mathrm{c}, \mathrm{d}}$ \\
\hline OV12 & $1.80^{\mathrm{d}}$ & $10.3 \pm 2.73^{\mathrm{e}, \mathrm{f}}$ & $39.6 \pm 3.60^{b, c, d}$ & $52.8 \pm 2.59^{a, b}$ & $0.76 \pm 0.10^{\mathrm{b}-\mathrm{e}}$ & $7.64 \pm 1.11^{b, c, d}$ \\
\hline OV13 & $1.96^{\mathrm{d}}$ & $12.3 \pm 4.03^{\mathrm{c}-\mathrm{f}}$ & $37.3 \pm 1.79 \mathrm{~b}, \mathrm{c}, \mathrm{d}$ & $54.0 \pm 3.88^{\mathrm{a}, \mathrm{b}}$ & $0.70 \pm 0.07^{\mathrm{b}-\mathrm{e}}$ & $8.70 \pm 2.94^{\mathrm{a}, \mathrm{b}, \mathrm{c}}$ \\
\hline OV14 & $2.35^{b, c}$ & $17.5 \pm 3.75^{\mathrm{c}, \mathrm{d}, \mathrm{e}}$ & $34.1 \pm 1.80^{\mathrm{c}, \mathrm{d}, \mathrm{e}}$ & $58.1 \pm 2.30^{\mathrm{a}}$ & $0.59 \pm 0.05^{\mathrm{c}, \mathrm{d}, \mathrm{e}}$ & $7.73 \pm 1.11^{b, c, d}$ \\
\hline OV16 & $2.26^{\mathrm{c}, \mathrm{d}}$ & $16.5 \pm 5.29^{c, d, e}$ & $33.3 \pm 2.70^{\mathrm{d}, \mathrm{e}}$ & $59.3 \pm 2.87^{\mathrm{a}}$ & $0.56 \pm 0.07^{\mathrm{d}, \mathrm{e}}$ & $7.64 \pm 3.15^{b, c, d}$ \\
\hline OV17 & $2.17^{c, d}$ & $14.9 \pm 2.39^{c-f}$ & $38.3 \pm 4.47^{b, c, d}$ & $52.8 \pm 7.21^{\mathrm{a}, \mathrm{b}}$ & $0.75 \pm 0.19^{b-e}$ & $8.85 \pm 3.61^{\mathrm{a}, \mathrm{b}, \mathrm{c}}$ \\
\hline OV18 & $1.48^{\mathrm{e}}$ & $7.24 \pm 3.81^{\mathrm{f}}$ & $30.3 \pm 0.98^{\mathrm{e}}$ & $59.1 \pm 1.44^{\mathrm{a}}$ & $0.51 \pm 0.02^{\mathrm{e}}$ & $10.7 \pm 1.70^{\mathrm{a}, \mathrm{b}}$ \\
\hline \multicolumn{7}{|c|}{ Oblačinska sour cherry-Locality Prokuplje } \\
\hline OV31 & $1.83^{\mathrm{d}}$ & $10.9 \pm 5.40^{\mathrm{d}, \mathrm{e}, \mathrm{f}}$ & $35.2 \pm 3.19^{b-e}$ & $58.4 \pm 3.42^{\mathrm{a}}$ & $0.61 \pm 0.09 \mathrm{c}, \mathrm{d}, \mathrm{e}$ & $6.42 \pm 1.67^{b, c, d}$ \\
\hline OV32 & $2.44^{b, c}$ & $19.0 \pm 5.38^{c, d}$ & $41.4 \pm 4.17^{\mathrm{b}}$ & $51.5 \pm 4.21^{\mathrm{a}, \mathrm{b}, \mathrm{c}}$ & $0.81 \pm 0.15^{b, c}$ & $7.03 \pm 0.80^{b, c, d}$ \\
\hline OV33 & $2.11^{c, d}$ & $14.1 \pm 3.09^{\mathrm{c}-\mathrm{f}}$ & $40.6 \pm 4.76^{b, c}$ & $51.8 \pm 4.51^{\mathrm{a}, \mathrm{b}, \mathrm{c}}$ & $0.80 \pm 0.16^{b, c, d}$ & $7.55 \pm 0.44^{b, c, d}$ \\
\hline OV34 & $2.51^{\mathrm{b}}$ & $20.8 \pm 10.5^{b, c}$ & $35.2 \pm 3.91^{\mathrm{b}-\mathrm{e}}$ & $54.9 \pm 9.18^{\mathrm{a}, \mathrm{b}}$ & $0.66 \pm 0.17^{\mathrm{b}-\mathrm{e}}$ & $9.85 \pm 7.16^{\mathrm{a}, \mathrm{b}}$ \\
\hline
\end{tabular}

Differences between mean values followed by the same letter were not significantly different according to Duncan's test $(p<0.05)$. 
Detailed analysis of secondary wood characteristics, particularly the vessel number and size, the main elements in water conduction, was carried out. European ground cherry genotypes followed a typical semi-ring porous pattern-the vessel lumen area decreased as the roots matured (from $944 \pm 72.9 \mu \mathrm{m}^{2}$ to $916 \pm 36.1 \mu \mathrm{m}^{2}$ in SV2, and from $1530 \pm 1307 \mu \mathrm{m}^{2}$ to $1399 \pm 921 \mu \mathrm{m}^{2}$ in SV4 (Table 3.), with a very similar number of vessels being formed across the zones (Table 4.). The decrease in vessel size observed in European ground cherry genotypes was not present in Oblačinska sour cherry. On the contrary in this species, regardless of the locality, genotypes formed greater vessels as the roots matured (Figure 2c-e), with the exception of two genotypes-OV14 and OV18. Regarding the localities, genotypes from Dešilovo formed thinner roots with only two zones for analysis-inner and outer (Figure 2c). Nevertheless, all Oblačinska sour cherry genotypes had very large vessel lumen areas, ranging from $701 \pm 92.9 \mu \mathrm{m}^{2}$ in the OV33 inner zone to $2353 \pm 676 \mu \mathrm{m}^{2}$ in the OV16 outer zone (Table 3). The average vessel lumen area of Oblačinska sour cherry roots from the locality of Dešilovo varied from $1333 \pm 204 \mu \mathrm{m}^{2}$ in OV13, to $2226 \pm 622 \mu \mathrm{m}^{2}$ in OV16, while in roots from the locality of Prokuplje, the average values ranged from $846 \pm 102 \mu \mathrm{m}^{2}$ in OV33, to $1685 \pm 220 \mu^{2}$ in OV31. The number of vessels decreased as the roots matured in genotypes derived from the locality of Dešilovo (exception OV14), and they increased in genotypes that were derived from the locality of Prokuplje (exception OV33) (Table 4).

Table 3. Average vessel size of different secondary root zones and complete cross-sectional area.

\begin{tabular}{|c|c|c|c|c|}
\hline Genotype & $\begin{array}{l}\text { Average Vessel } \\
\text { Lumen Area in } \\
\text { External Root } \\
\text { Wood Zone }\left(\mu \mathrm{m}^{2}\right)\end{array}$ & $\begin{array}{l}\text { Average Vessel } \\
\text { Lumen Area in } \\
\text { Middle root Wood } \\
\text { Zone }\left(\mu \mathrm{m}^{2}\right)\end{array}$ & $\begin{array}{l}\text { Average Vessel } \\
\text { lumen Area in } \\
\text { Inner Root Wood } \\
\text { Zone }\left(\mu \mathrm{m}^{2}\right)\end{array}$ & $\begin{array}{l}\text { Average Vessel } \\
\text { Lumen Area on } \\
\text { Complete } \\
\text { Cross-Section }\left(\mu \mathrm{m}^{2}\right)\end{array}$ \\
\hline \multicolumn{5}{|c|}{ European ground cherry-Locality Fruška gora } \\
\hline SV2 & $916 \pm 36.1^{d}$ & $917 \pm 82.0^{c}$ & $944 \pm 72.9^{\mathrm{c}, \mathrm{d}}$ & $926 \pm 28.8^{\mathrm{c}, \mathrm{d}}$ \\
\hline SV4 & $1399 \pm 921^{b, c, d}$ & $1528 \pm 841^{\mathrm{a}}$ & $1530 \pm 1307^{\mathrm{a}, \mathrm{b}, \mathrm{c}}$ & $1486 \pm 1023^{b, c}$ \\
\hline \multicolumn{5}{|c|}{ Oblačinska sour cherry-Locality Dešilovo } \\
\hline OV11 & $1511 \pm 243^{b, c, d}$ & $/ d$ & $1468 \pm 140^{\mathrm{a}, \mathrm{b}, \mathrm{c}}$ & $1489 \pm 154^{b, c}$ \\
\hline OV12 & $1609 \pm 350^{b, c}$ & $/ \mathrm{d}$ & $1414 \pm 431^{\mathrm{b}, \mathrm{c}}$ & $1512 \pm 382^{b}$ \\
\hline OV13 & $1402 \pm 245^{b, c, d}$ & $/ d$ & $1264 \pm 182^{b, c, d}$ & $1333 \pm 204^{b, c, d}$ \\
\hline OV14 & $1420 \pm 212^{b, c, d}$ & $/ d$ & $1630 \pm 235^{\mathrm{a}, \mathrm{b}}$ & $1525 \pm 204^{b}$ \\
\hline OV16 & $2353 \pm 676^{\mathrm{a}}$ & $/ d$ & $2099 \pm 634^{a}$ & $2226 \pm 622^{a}$ \\
\hline OV17 & $2042 \pm 225^{a, b}$ & $/ d$ & $1370 \pm 228^{b, c}$ & $1706 \pm 208^{b}$ \\
\hline OV18 & $1276 \pm 341^{\mathrm{c}, \mathrm{d}}$ & $/^{\mathrm{d}}$ & $1524 \pm 282^{a, b, c}$ & $1400 \pm 309^{b, c}$ \\
\hline \multicolumn{5}{|c|}{ Oblačinska sour cherry-Locality Prokuplje } \\
\hline OV31 & $1719 \pm 220^{b, c}$ & $1685 \pm 102^{\mathrm{a}}$ & $1651 \pm 298^{\mathrm{a}, \mathrm{b}}$ & $1685 \pm 220^{b}$ \\
\hline OV32 & $1355 \pm 284^{b, c, d}$ & $1220 \pm 30.2^{b}$ & $1195 \pm 290^{b, c, d}$ & $1257 \pm 189^{b, c, d}$ \\
\hline OV33 & $898 \pm 31.7^{\mathrm{d}}$ & $939 \pm 271^{c}$ & $701 \pm 92.9^{d}$ & $846 \pm 102^{d}$ \\
\hline OV34 & $1472 \pm 864^{b, c, d}$ & $1329 \pm 101^{\mathrm{a}, \mathrm{b}}$ & $1051 \pm 468^{\mathrm{b}, \mathrm{c}, \mathrm{d}}$ & $1284 \pm 471^{b, c, d}$ \\
\hline
\end{tabular}

Differences between mean values followed by the same letter were not significantly different according to Duncan's test $(p<0.05)$. 
Table 4. Average vessel number of different secondary root zones and complete cross-sectional area.

\begin{tabular}{|c|c|c|c|c|}
\hline Genotype & $\begin{array}{l}\text { Average Vessel } \\
\text { Number in } \\
\text { External Root } \\
\text { Wood Zone }\end{array}$ & $\begin{array}{l}\text { Average Vessel } \\
\text { Number in } \\
\text { Middle Root } \\
\text { Wood Zone }\end{array}$ & $\begin{array}{l}\text { Average Vessel } \\
\text { Number in } \\
\text { Inner Root } \\
\text { Wood Zone }\end{array}$ & $\begin{array}{l}\text { Average Vessel } \\
\text { Number on the } \\
\text { Complete } \\
\text { Cross-Section }\end{array}$ \\
\hline \multicolumn{5}{|c|}{ European ground cherry-Locality Fruška gora } \\
\hline SV2 & $94.7 \pm 9.98^{\mathrm{a}, \mathrm{b}}$ & $79.6 \pm 8.52^{\mathrm{c}}$ & $90.0 \pm 21.3^{\mathrm{c}, \mathrm{d}}$ & $88.1 \pm 13.3^{\mathrm{c}, \mathrm{d}}$ \\
\hline SV4 & $82.4 \pm 12.0^{b}$ & $78.1 \pm 1.98^{c}$ & $88.0 \pm 4.01^{\mathrm{d}}$ & $82.8 \pm 2.00^{\mathrm{d}}$ \\
\hline \multicolumn{5}{|c|}{ Oblačinska sour cherry-Locality Dešilovo } \\
\hline OV11 & $85.8 \pm 14.4^{b}$ & $/ d$ & $90.3 \pm 10.5^{b, c, d}$ & $88.1 \pm 10.1^{\mathrm{c}, \mathrm{d}}$ \\
\hline OV12 & $92.0 \pm 19.0^{\mathrm{a}, \mathrm{b}}$ & $/ \mathrm{d}$ & $106 \pm 3.10^{\mathrm{a}-\mathrm{d}}$ & $98.9 \pm 9.03^{\mathrm{a}-\mathrm{d}}$ \\
\hline OV13 & $94.5 \pm 13.6^{\mathrm{a}, \mathrm{b}}$ & $/^{\mathrm{d}}$ & $97.6 \pm 14.0^{b, c, d}$ & $94.5 \pm 13.6^{\mathrm{c}, \mathrm{d}, \mathrm{e}}$ \\
\hline OV14 & $127 \pm 15.6^{\mathrm{a}}$ & $/^{\mathrm{d}}$ & $113 \pm 31.3^{\mathrm{a}-\mathrm{d}}$ & $114 \pm 17.9^{\mathrm{a}, \mathrm{b}}$ \\
\hline OV16 & $105 \pm 12.9^{\mathrm{a}, \mathrm{b}}$ & $/^{\mathrm{d}}$ & $120 \pm 5.82^{a, b, c}$ & $113 \pm 8.31^{\mathrm{a}, \mathrm{b}}$ \\
\hline OV17 & $87.4 \pm 12.4^{b}$ & $/^{\mathrm{d}}$ & $126 \pm 21.9^{\mathrm{a}}$ & $107 \pm 11.0^{\mathrm{a}, \mathrm{b}, \mathrm{c}}$ \\
\hline OV18 & $95.9 \pm 27.1^{\mathrm{a}, \mathrm{b}}$ & $/^{\mathrm{d}}$ & $106 \pm 15.8^{a-d}$ & $101 \pm 20.5^{\mathrm{a}-\mathrm{s}}$ \\
\hline \multicolumn{5}{|c|}{ Oblačinska sour cherry_Locality Prokuplje } \\
\hline OV31 & $112 \pm 20.4^{\mathrm{a}, \mathrm{b}}$ & $109 \pm 6.75^{\mathrm{a}, \mathrm{b}}$ & $107 \pm 8.86^{\mathrm{a}-\mathrm{d}}$ & $110 \pm 8.71^{\mathrm{a}, \mathrm{b}, \mathrm{c}}$ \\
\hline OV32 & $109 \pm 16.5^{\mathrm{a}, \mathrm{b}}$ & $111 \pm 9.28^{\mathrm{a}, \mathrm{b}}$ & $109 \pm 26.9^{a-d}$ & $110 \pm 16.8^{\mathrm{a}, \mathrm{b}, \mathrm{c}}$ \\
\hline OV33 & $88.8 \pm 15.5^{b}$ & $102 \pm 26.6^{b}$ & $118 \pm 27.4^{\mathrm{a}-\mathrm{d}}$ & $103 \pm 11.8^{\mathrm{a}-\mathrm{d}}$ \\
\hline OV34 & $125 \pm 49.6^{\mathrm{a}}$ & $116 \pm 16.2^{\mathrm{a}}$ & $121 \pm 17.6^{\mathrm{a}, \mathrm{b}}$ & $121 \pm 25.7^{\mathrm{a}}$ \\
\hline
\end{tabular}

Differences between mean values followed by the same letter were not significantly different according to Duncan's test $(p<0.05)$.

\subsection{Meteorological Characteristics During Root Secondary Thickening}

Weather conditions during the vegetation of 2010 when root growth was the most prominently varied among the investigated locations.

\subsubsection{Fruška Gora}

The monthly precipitation ranged from $82.6 \mathrm{~mm}$ in May, down to $16.5 \mathrm{~mm}$ in August (Figure 3), with the emphasis that May rainfall occurred in only three rainy episodes: 15 to 18 May $(37.9 \mathrm{~mm})$, 23rd May $(10.8 \mathrm{~mm})$, and 31 May $(20.6 \mathrm{~mm})$. A number of $\mathrm{PPT}_{0}$ days varied, from nine days in June to 18 days in August, reaching up to 11-18 in the other four investigated months (Figure 3). Observed monthly, $\mathrm{PPT}_{<5 \mathrm{~mm}}$ varied from 24 (June and July) to 28 (March). When observed continuously throughout the vegetation $\mathrm{PPT}_{<5 \mathrm{~mm}}$ reached up to 38 days in June-July (data not shown). Average monthly temperature regularly increased from 7.44 to $23.29^{\circ} \mathrm{C}$, while the monthly sum of temperatures ranged from 230.7 (March) to $721.9^{\circ} \mathrm{C}$ (August). A number of very hot days with maximum daily temperatures over $30^{\circ} \mathrm{C}$ was 10,14 , and 14 in June, July, and August, respectively (Figure 4).

\subsubsection{Dešilovo}

The monthly precipitation ranged from $44.7 \mathrm{~mm}$ in May down to $5.26 \mathrm{~mm}$ in August (Figure 3), with more than a half of May rainfall $(26.28 \mathrm{~mm})$ occurring in the previously mentioned rainy episode (15 to 18 May). A number of $\mathrm{PPT}_{0}$ days varied from nine days in June, to 27 days in August, achieving values of 12-19 in the other four investigated months (Figure 3). Observed monthly, $\mathrm{PPT}_{<5 \mathrm{~mm}}$ varied from 25 (June) to 31 (August). Continuously throughout the vegetation, $\mathrm{PPT}_{<5 \mathrm{~mm}}$ reached up to 44 (March-April) and 60 (July-August). The average monthly temperature regularly increased from 6.85 to $23.15^{\circ} \mathrm{C}$ while the monthly sum of the temperatures ranged from 212.2 to $717.8^{\circ} \mathrm{C}$, respectively. A number of very hot days with maximum daily temperatures of over $30^{\circ} \mathrm{C}$ occurred, numbering 1,7 , 12, and 16 days from April to August, respectively (Figure 4). 


\subsubsection{Prokuplje}

The monthly precipitation ranged from $55.8 \mathrm{~mm}$ in June down to $11.9 \mathrm{~mm}$ in August (Figure 3). The number of $\mathrm{PPT}_{0}$ varied from eight days in June to 24 days in August, reaching 11-16 days in the other four investigated months (Figure 3). Observed monthly, $\mathrm{PPT}_{<5 \mathrm{~mm}}$ varied from 24 (June) to 30 (August). When observed continuously throughout the vegetation, $\mathrm{PPT}_{<5 \mathrm{~mm}}$ reached up to 30 (March-April) and 36 (July-August). The average monthly temperature regularly increased from 7.18 to $22.90{ }^{\circ} \mathrm{C}$ while the monthly sum of temperatures ranged from 222.7 to $710.3^{\circ} \mathrm{C}$. A number of very hot days with maximum daily temperatures of over $30^{\circ} \mathrm{C}$ occurred, numbering 9,11 , and 10 days in June, July, and August, respectively (Figure 4).

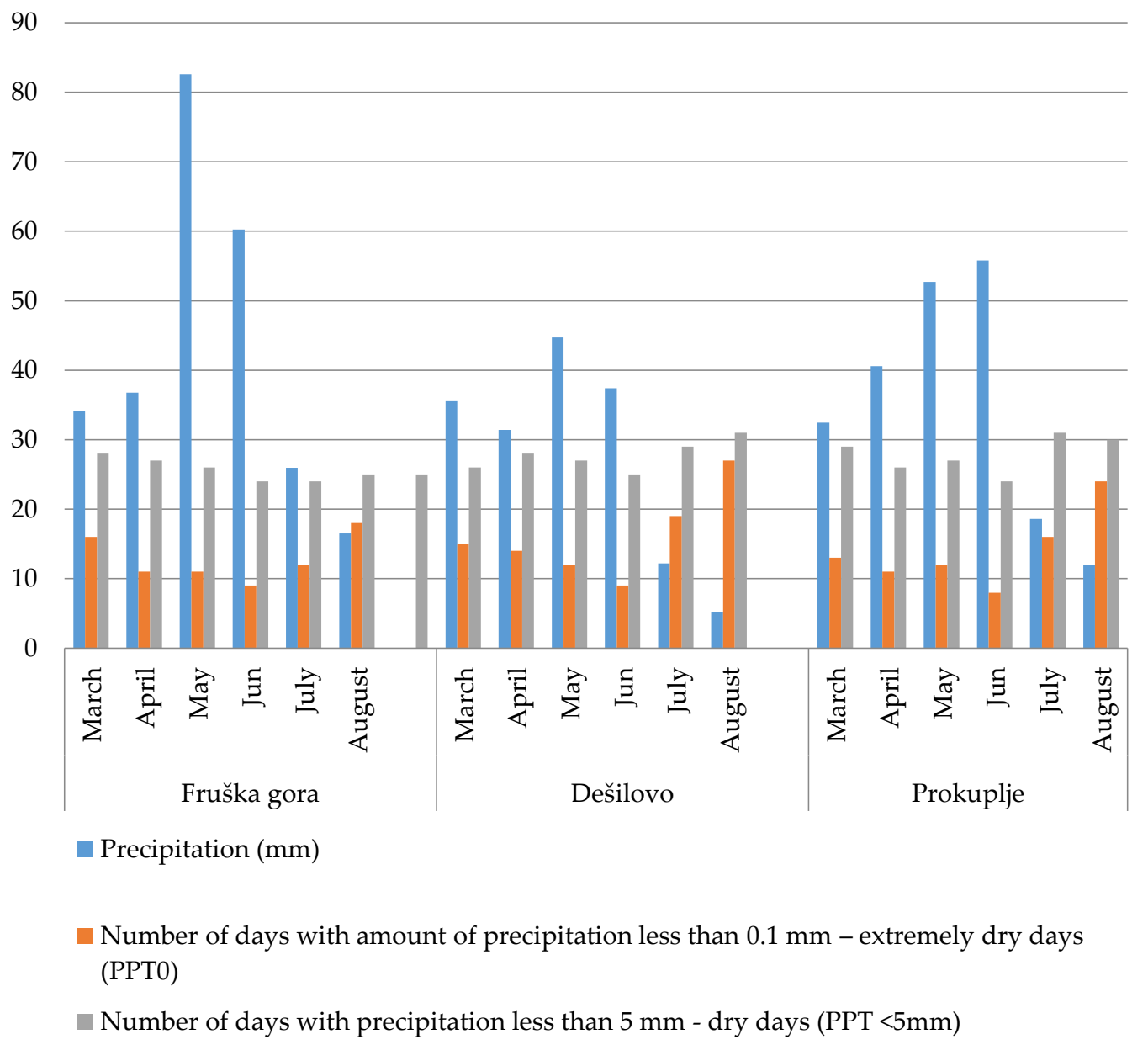

Figure 3. Variations of precipitation, number of extremely dry days, and duration of the dry period for selected regions during the March-August period of 2010. 


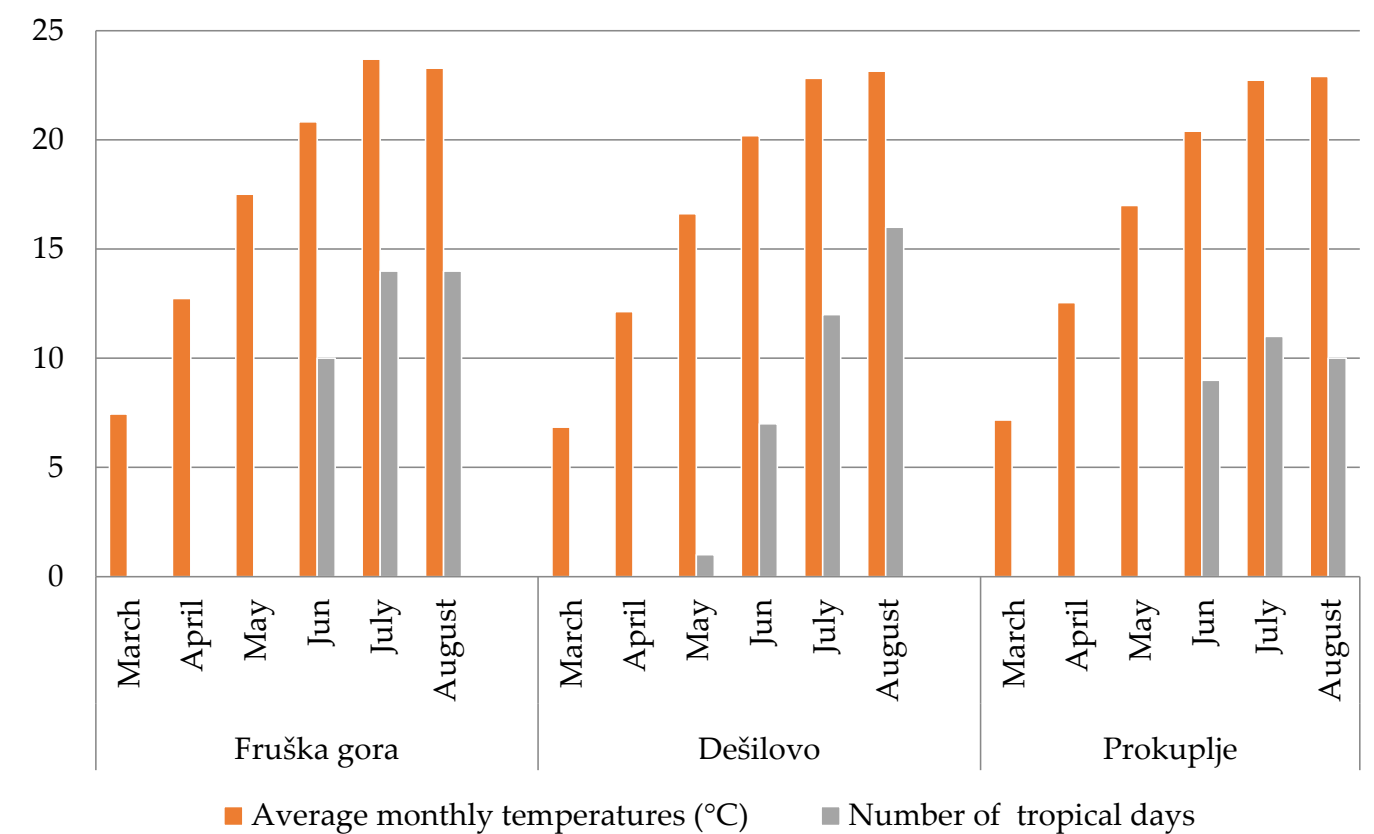

Figure 4. Variation of average monthly temperatures and number of very hot days with maximum temperatures $>30{ }^{\circ} \mathrm{C}$ during the March-August period of 2010 .

\subsection{Correlation Analysis of the Investigated Anatomical Characteristics and Weather Conditions}

Correlation analysis was performed in order to reveal how the root cambial activity and xylem formation responded to variations of meteorological conditions during the vegetation period. Overall precipitation and its monthly distribution (except for March and April), as well as the monthly sum of temperatures and the monthly average temperatures (except for August), were in statistically significant positive correlations with the cross-sectional area, the percentage of secondary wood area, and the wood/cortex ratio, whilst they were in statistically significant negative correlation with the percentage of the secondary cortex area (Supplementary 1 and 2).

Specific correlations that emerged as the most significant were very indicative. The number of dry days $-\mathrm{PPT}_{<5 \mathrm{~mm}}$ during May, July, and August, as well as the continuous dry days in May-June and July-August were in a statistically significant negative correlation with the above-mentioned cross-sectional characteristics, whilst they were in a positive correlation with the secondary cortex percentage, the average vessel number in the inner root zone, and the average vessel number on a complete cross-section area. In June, there were similar correlations with cross-section characteristics, but with lower correlations coefficients.

Middle root zone characteristics—-the average vessel lumen area and the average vessel number, were in a statistically significant positive correlation with $\mathrm{PPT}_{<5 \mathrm{~mm}}$ in March, whilst they were negative with all other analyzed months and continuous dry periods (Table 5). 
Table 5. Correlation coefficients of investigated anatomical characteristics and a number of dry days with precipitation less than $5 \mathrm{~mm}\left(\mathrm{PPT}_{<5 \mathrm{~mm}}\right)$ observed monthly and continuously trough vegetation.

\begin{tabular}{|c|c|c|c|c|c|c|c|c|c|}
\hline $\begin{array}{c}\text { Anatomical } \\
\text { Characteristic/Month }\end{array}$ & March & April & May & June & July & August & May-June & June-July & July-August \\
\hline Cross-section radius (mm) & 0.40 & -0.30 & -0.80 & -0.56 & -0.65 & -0.83 & -0.75 & 0.29 & -0.57 \\
\hline Cross-section area (mm2) & 0.40 & -0.29 & -0.85 & -0.57 & -0.70 & -0.87 & -0.77 & 0.33 & -0.58 \\
\hline Secondary wood area (\%) & 0.38 & -0.30 & $\overline{-0.66}$ & $\overline{-0.50}$ & -0.57 & $\overline{-0.69}$ & -0.65 & 0.20 & $\overline{-0.52}$ \\
\hline Secondary cortex area $(\%)$ & -0.41 & 0.32 & $\underline{0.77}$ & $\underline{0.56}$ & $\underline{0.61}$ & $\underline{0.80}$ & $\underline{0.73}$ & -0.25 & $\underline{0.57}$ \\
\hline Wood/cortex ratio & 0.38 & -0.29 & $\overline{-0.78}$ & $\overline{-0.54}$ & $\overline{-0.64}$ & $\overline{-0.81}$ & $\overline{-0.73}$ & 0.29 & $\overline{-0.56}$ \\
\hline Periderm area (\%) & -0.03 & 0.04 & $\overline{-0.05}$ & 0.01 & $\overline{-0.07}$ & $\overline{-0.04}$ & $\overline{-0.01}$ & 0.07 & 0.01 \\
\hline AVL External root wood zone & -0.43 & 0.39 & 0.37 & 0.48 & 0.21 & 0.44 & 0.51 & 0.07 & 0.48 \\
\hline AVL Middle root wood zone & 0.76 & -0.70 & -0.55 & -0.83 & -0.25 & -0.67 & -0.84 & -0.21 & -0.83 \\
\hline AVL Inner root wood zone & $\overline{-0.53}$ & $\overline{0.52}$ & 0.17 & $\overline{0.53}$ & -0.04 & $\overline{0.27}$ & $\overline{0.46}$ & 0.31 & $\overline{0.52}$ \\
\hline AVL Complete cross-section & -0.50 & 0.47 & 0.29 & 0.52 & 0.10 & 0.38 & 0.51 & 0.19 & 0.53 \\
\hline AVN External root wood zone & 0.24 & -0.29 & 0.35 & -0.13 & 0.45 & 0.27 & 0.05 & -0.47 & -0.12 \\
\hline AVN Middle root wood zone & $\underline{0.64}$ & -0.60 & -0.48 & -0.71 & -0.23 & -0.59 & -0.72 & -0.17 & -0.71 \\
\hline AVN Inner root wood zone & 0.06 & -0.14 & $\underline{0.61}$ & 0.10 & $\underline{0.65}$ & $\underline{0.56}$ & 0.33 & -0.53 & 0.11 \\
\hline AVN Complete cross-section & 0.18 & -0.27 & $\overline{0.65}$ & 0.00 & $\overline{0.73}$ & $\underline{0.56}$ & 0.22 & -0.68 & 0.02 \\
\hline
\end{tabular}

AVL-average vessel lumen area; AVN-average vessel number; statistically significant correlation coefficients are underlined.

A number of very hot days showed fewer but specific correlations (Table 6). A number of very hot days in May and June negatively correlated with the cross-section radius and area, as well as the wood/cortex ratio, whilst those days in July showing statistically significant positive correlations. An opposite relationship was noted for a percentage of the secondary cortex area. A number of very hot days in May and June negatively correlated with the average vessel size and number in the middle root zone. Statistically significant and high negative correlations $(r=-0.73)$ were noted for a number of very hot days during July, and the average vessel number in a total cross-section.

Table 6. Correlation coefficients of the investigated anatomical characteristics and a number of very hot days $\left(\mathrm{T}_{\max }>30^{\circ} \mathrm{C}\right)$.

\begin{tabular}{ccccc}
\hline Anatomical Characteristic/Month & May & June & July & August \\
\hline Cross-section radius (mm) & $\underline{-0.56}$ & $\underline{-0.70}$ & $\underline{-0.62}$ & -0.19 \\
Cross-section area $\left(\mathrm{mm}^{2}\right)$ & $\underline{-0.50}$ & $\underline{-0.72}$ & $\underline{0.66}$ & -0.18 \\
Secondary wood area (\%) & $\underline{0.56}$ & $\underline{0.69}$ & $\underline{-0.48}$ & -0.21 \\
Secondary cortex area (\%) & -0.54 & $\underline{-0.68}$ & $\underline{-0.60}$ & -0.18 \\
Wood/cortex ratio & 0.01 & 0.00 & 0.07 & 0.04 \\
Periderm area (\%) & 0.48 & -0.51 & -0.17 & 0.34 \\
AVL External root wood zone & $\underline{-0.83}$ & $\underline{0.85}$ & 0.19 & -0.33 \\
AVL Middle root wood zone & 0.53 & -0.48 & 0.08 & 0.50 \\
AVL Inner root wood zone & -0.13 & -0.52 & -0.06 & 0.43 \\
AVL Complete cross-section & $\underline{-0.71}$ & $\underline{-0.73}$ & -0.46 & -0.34 \\
AVN External root wood zone & 0.10 & -0.26 & -0.44 & -0.53 \\
AVN Middle root wood zone & 0.00 & -0.19 & $\underline{-0.73}$ & -0.36 \\
AVN Inner root wood zone & &
\end{tabular}

$\mathrm{AVL}$-average vessel lumen area; $\mathrm{AVN}$-average vessel number; statistically significant correlation coefficients are underlined.

\section{Discussion}

The root system is generally supported and buffered by the surrounding soil. With such assistance, roots are able to develop large conduits with a lower risk of hydraulic pathway breakage [4]. However, this soil-mediated protection is diminished if drought events last for a long time and are followed by the heavy rainfalls, especially if the root system is shallow. As the root system is the 'hidden half' [22], it is very difficult to evaluate; even with the modern technologies and approaches, more in-depth analysis across the plant taxa is required. In rootstock breeding, this hidden half is actually the 'major half', of the importance for future grafted trees' performances. The occurrence of the plasticity in stems' responses directed towards improved water use efficiency during drought events might be of even greater importance in roots, due to their function in water and nutrient uptake. In the presented study, root plasticity varied between species and the levels of structural shifts. 
European ground cherry genotypes followed typical semi-ring porous patterns-vessel size decreased as the roots matured, with a very similar number of vessels being formed across the zones. European ground cherry mother trees from which roots were collected received higher amounts of precipitation during May $(82.6 \mathrm{~mm})$ and June $(60.2 \mathrm{~mm})$, resulting in a more moderate response to the atmospheric conditions compared to Oblačinska sour cherry (Figure 2).

As for the structural shifts, the first clearly obvious modification was the overall radial growth expressed through the cross-sectional radius and area. It seems that the decrease in root diameter is a trait for increasing the plant acquisition of limited water and productivity under drought [23]. Annual ring width reduction is also a very common response in branches forming during high temperatures and limited precipitation conditions $[9,11,17]$. In the present study, monthly precipitation as well as the monthly sum of temperatures in general positively affected radial growth, especially secondary wood-xylem formation. However, the scarce and uneven distribution of precipitations constrained secondary thickening.

Treder and Konopacki [24] discussed the significance of 2.5 and $5 \mathrm{~mm}$ of precipitation thresholds for orchard water balance, emphasizing the complexity of interaction between rainfall and temperature, as well as the amount and intensity of precipitation. It was noted that the $5 \mathrm{~mm}$ threshold could be sufficient if the rain is light and continues over a couple of days. In the present study, the number of dry days- $-\mathrm{PPT}_{<5 \mathrm{~mm}}$ during May, July, and August were in a statistically significant negative correlation with radial secondary growth-cross-section area, percentage of secondary wood area, and wood/cortex ratio. Investigating xylem plasticity in Larix decidua and Picea abies, Bryukhanova and Fonti [8] described the site climate conditions as dry-summer months with day temperatures from 25 to $35^{\circ} \mathrm{C}$, and little monthly precipitation $(45 \mathrm{~mm}$ ), causing annual xylem adjustments. Other authors also emphasized $40-50 \mathrm{~mm}$ of monthly precipitation as a threshold for trees' successful growth $[25,26]$. Investigating the growth patterns of mangrove trees, Menezes et al. [27] observed that a lesser tree ring width was closely related to a number of months with less than $50 \mathrm{~mm}$ of precipitation.

As for the fruiting trees, the general orchard requirements for successful fruiting and bud formation for the next year are $600-900 \mathrm{~mm}$ of precipitation during vegetation [28]. An ideal distribution of that amount of precipitation should be around $100 \mathrm{~mm}$ per month i.e., $25 \mathrm{~mm}$ per week. From investigating irrigation requirements for peach orchards, it was concluded that depending on the cultivation system, the monthly needs during June, July, and August varied from 46 to $65 \mathrm{~mm}$, 88-121 mm, and 121-162 mm, respectively [29]. Considering these observations during the entire growing season, roots from the locality of Dešilovo grew in dry conditions-a lack of precipitation, since monthly precipitation did not exceed $45 \mathrm{~mm}$, whilst roots from the other two localities faced this constraint during July and August. Altogether, with a number of continuous dry days, this has led to such growth stagnation that cross-sections from Dešilovo were one complete wood zone thinner.

In some root cross-sections, there were traces of very thin middle wood zone (Figure 2d), while in others it did not appear. These conditionally divided zones for measurement purposes corresponded to false wood rings with shifts in vessel lumen areas from larger to smaller, which was characteristic of semi-ring porous species. The transition from one to another false ring was very noticeable, due to differences in vessel sizes and density, as well as the prominent region of differently colored very dense wood that occurred between rings in most of the investigated genotypes (Figure 2). Both species did not cease their growth and vessel production prematurely due to drought events late in the summer, as would be expected, but they differed in newly produced xylem conduit sizes. In poplar trees (Populus nigra L. $\times$ P. maximowiczii, clone Kamabuchi), Arend and Fromm [30] also reported a strong seasonally dependent pattern-the development of xylem elements was much more sensitive to drought in early than in late summer. European ground cherry genotypes, characterized by deeper, vertically oriented root systems, produced smaller late summer vessels compared to those from late spring and early summer. On the contrary, roots of the Oblačinska sour cherry shallow root system produced larger late summer vessels compared to those that formed earlier during vegetation. In previous anatomical research conducted on standard cherry rootstocks of different size-controlling 
capacities, the rootstocks 'Colt' and 'PHL-A', also characterized by shallow, horizontally oriented root systems [31], showed the same increase in vessels size as in 'Oblačinska', whilst other three did not follow this pattern [21].

Reviewing the growth dynamics in tropical trees, Worbes [25] have shown that even regular shoot rings can form two small false rings related to two occasions of precipitation during the dry season, with $50 \mathrm{~mm}$ rainfall over one or two days, followed by dry periods of up to three weeks. According to this study, during alternating periods of rainfall and drought, cambial activity started and stopped within short periods, resulting in two small rings, which was the case in the investigated cherry roots. Dry periods with 38 (Fruška gora), 60 (Dešilovo), and 36 (Prokuplje) dry days, resulted in a different number of false growth rings (three or two) imprinted in the analyzed roots. There is an indication of a relation between dry periods-rainy episodes, and the occurrence of intra-annual root xylem rings with the ability for wide conduit production after cambial activity evocation. This seems to be the compensation for reduced radial growth and lesser wood area. It was previously suggested by Ljubojević [3] that 'Oblačinska' sour cherry might have a unique strategy that enables it to supply shoots with a sufficient amount of water and nutrients. Large xylem conduits with a low resistance to water flow and high theoretical hydraulic capacity might compensate for lower water uptake from shallower and lesser-branched root systems. A similar pattern was noted by Singh et al. [32] on the rice root's anatomical and histological shifts towards larger xylem vessels under water stress in resistant genotypes. The same strategy was concluded by Von Arx et al. [13], where upon release from drought stress, long-living perennial herb plants of Potentilla diversifolia were able to shift the vessel sizes towards larger diameters, enabling them to utilize increased soil moisture.

Overall precipitation and its monthly distribution, as well as the sum of temperatures and monthly average temperatures (except for August), positively correlated with the percentage of the secondary wood area and wood/cortex ratio, whilst it negatively correlated with the percentage of secondary cortex area. On the contrary, due to the obtained correlation matrices, it seems that a number of continuous days with negligible or absent precipitation $\left(\mathrm{PPT}_{<5 \mathrm{~mm}}\right)$ promoted secondary cortex (phloem) formation. A greater phloem portion under drought stress might be a strategy to amplify the storage capacity for the photoassimilates needed for the growth and development that emerges upon drought release.

The most interesting shift in vessel lumen area due to reduced precipitation in July and August was the production of larger vessels in the investigated 'Oblačinska' sour cherry roots as they matured. According to Eilmann et al. [33], the increased lumen diameter mitigated the reduction in the conducting area caused by drought, and reduced tree-ring widths due to the fourth power relation to the conduit diameter (Hagen Poiseuille's law according to [7,21,34-36]). Drought induced larger vessel lumen diameters, and consequently higher specific hydraulic conductivity in ponderosa pine growing at a semi-arid site compared to a moderate mountain site, were previously reported by Maherali and DeLucia [37]. Very specific statistically significant positive correlations occurred between the average vessel number on complete cross-section and $\mathrm{PPT}_{<5 \mathrm{~mm}}$ in May, June, and July. This suggests that the cherry root maintenance strategy is to mitigate the reduced wood area during drought events, and vice versa; when wood growth is promoted, vessel number was reduced.

Although changing environmental conditions did trigger the shift of large and small vessels, as well as the occurrence of false rings, it seems that their size was mainly genetically controlled. The scarcity of statistically significant correlations implies that there is an inherited mechanism that keeps vessel size under internal control.

\section{Conclusions}

The assumed impact of atmospheric conditions on cherry root cambial plasticity in this study was fortified by the occurrence of false rings and alterations in conduit sizes in secondary roots collected from in vivo mother plants, and their absence in clonally propagated roots of the same age and genotypes. Under atmospheric impacts, both of the investigated species altered their radial root 
growth imprinting stops and starts in a cambial activity that resulted in the occurrence of intra-annual false rings. Along with the false rings, European ground cherry followed a usual early-late wood pattern, while Oblačinska sour cherry produced larger vessels as an alternative to smaller cross-sections, and a weaker shallow root system. Although this represents its valuable ability to actively respond to temporal environmental challenges, priority should be narrowed to the Oblačinska sour cherry genotypes with moderate vessel lumen areas, due to the profound vulnerability of large conduits to embolism/cavitation. Changing atmospheric conditions triggered the shifts of large and small vessels throughout the false rings, but their size seems to be mainly genetically controlled. Taking into consideration all the above, genotypes with moderate vessel lumen areas-less than or around 1200 $\mu \mathrm{m}^{2}$ in the inner zone, as well as no greater than $1500 \mu \mathrm{m}^{2}$ in the outer zone-are presumed to be both size-controlling and stable upon the drought events. Thus, further field trials will be focused on the SV2 European ground cherry genotype, and the OV13, OV32, and OV34 Oblačinska sour cherry genotypes.

With the changing environment, rootstock breeding selection goals are to be changed accordingly. The preferred rootstocks should be able to cope with an uneven distribution of precipitation and increased temperatures during the late spring and summer months. For future breeding purposes and for the development of size-controlling prediction models, equal importance should be given to the determination of environmentally related xylem plasticity, as well as genetically controlled conduit size. Investigations of the cherry genepool indicated its ability to optimize its intra-annual anatomical architecture to the specific environment, adjusting both secondary wood and secondary cortex characteristics, which should be further investigated inter-annually.

Supplementary Materials: Supplementary materials can be found at http://www.mdpi.com/2073-4433/9/9/358/s1.

Author Contributions: V.O., I.M. and M.L. conceived and designed the experiments; M.L. and J.D. performed the experiments; T.N. and M.M. analyzed the data; G.B. contributed reagents/materials/analysis tools; M.L. wrote the paper; B.L. and L.D. contributed in weather data analysis and paper discussion, and N.M. contributed to the paper discussion.

Funding: This research was funded by the European Union's Horizon 2020 research and innovation program under grant number No. 691998. This research was partly supported and funded by the Ministry of Education and Science, Republic of Serbia, as one of the research topics in the frame of the project 'Selection of sweet and sour cherry dwarfing rootstocks and development of intensive cultivation technology based on sustainable agriculture principles' evidence number TR 31038, as well as the project 'Studying climate change and its influence on the environment: impacts, adaptation and mitigation' evidence number III 43007. The part of the research was conducted with the support of the "Start up for Science" program raised by the Philip Morris Company and the Centre for leadership development, the organization implementing the program. Open access publication of this research was funded by the European Union's Horizon 2020 research and innovation program “H2020 SERBIA FOR EXCELL" under grant agreement No. 691998.

Acknowledgments: This research was supported and funded by the Ministry of Education and Science, Republic of Serbia, as one of the research topics in the frame of the project 'Selection of sweet and sour cherry dwarfing rootstocks and development of intensive cultivation technology based on sustainable agriculture principles' evidence number TR 31038, as well as the project 'Studying climate change and its influence on the environment: impacts, adaptation and mitigation' evidence number III 43007. The part of the research was conducted with the support of the "Start up for Science" program raised by the Philip Moris Company and the Centre for leadership development, the organization implementing the program. This paper is supported by the H2020-TWINN-2015 'SERBIA FOR EXCELL' project. This project has received funding from the European Union's Horizon 2020 research and innovation program under grant agreement No. 691998.

Conflicts of Interest: The authors declare no conflict of interest. The founding sponsors had no role in the design of the study; in the collection, analyses, or interpretation of data; in the writing of the manuscript, and in the decision to publish the results.

\section{References}

1. Faostat. 2010. Available online: www.faostat.fao.org (accessed on 2 November 2010).

2. Habib, M.; Bhat, M.; Dar, B.N.; Wani, A.A. Sweet cherries from farm to table: A review. Crit. Rev. Food Sci. 2017, 57, 1638-1649. [CrossRef] [PubMed] 
3. Ljubojević, M.; Zorić, L.; Maksimović, I.; Dulić, J.; Miodragović, M.; Barać, G.; Ognjanov, V. Anatomically assisted cherry rootstock selection. Sci. Hortic. 2017, 217, 197-208. [CrossRef]

4. Baas, P.; Ewers, F.W.; Davis, S.D.; Wheeler, E.A. Evolution of xylem physiology. In The Evolution of Plant Physiology; Hemsley, A.R., Poole, I., Eds.; Elsevier Academic Press: London, UK; San Deigo, CA, USA, 2004; pp. 273-295.

5. Ljubojević, M.; Ognjanov, V.; Zorić, L.; Maksimović, I.; Merkulov, L.; Bošnjaković, D.; Barać, G. Modeling of water movement trough cherry plant as preselecting tool for prediction of tree vigor. Sci. Hortic. 2013, 160, 189-197. [CrossRef]

6. Hajagos, A.; Végvári, G. Investigation of tissue structure and xylem anatomy of eight rootstocks of sweet cherry (Prunus avium L.). Trees Struct. Funct. 2013, 27, 53-60. [CrossRef]

7. Tyree, M.T.; Sperry, J.S. Do woody plants operate near the point of catastrophic xylem dysfunction caused by dynamic water stress? Answers from a model. Plant Physiol. 1988, 88, 574-580. [CrossRef] [PubMed]

8. Bryukhanova, M.; Fonti, P. Xylem plasticity allows rapid hydraulic adjustment to annual climatic variability. Trees Struct. Funct. 2013, 27, 485-496. [CrossRef]

9. Lovisolo, C.; Schubert, A. Effects of water stress on vessel size and xylem hydraulic conductivity in Vitis vinifera L. J. Exp. Bot. 1998, 49, 693-700. [CrossRef]

10. Curtu, A.L.; Alizoti, P.; Ballian, D. Marginal/peripheral populations of forest tree species and their conservation status: Report for southeastern Europe. Ann. Silvic. Res. 2018, 41, 42-47. [CrossRef]

11. Fonti, P.; von Arx, G.; García-González, I.; Eilmann, B.; Sass-Klaassen, U.; Gärtner, H.; Eckstein, D. Studying global change through investigation of the plastic responses of xylem anatomy in tree rings. New Phytol. 2010, 185, 42-53. [CrossRef] [PubMed]

12. Rossi, S.; Deslauriers, A.; Anfodillo, T. Assessment of cambial activity and xylogenesis by microsampling tree species: An example at the Alpine timberline. Iawa. J. 2006, 27, 383-394. [CrossRef]

13. Von Arx, G.; Archer, S.R.; Hughes, M.K. Long-term functional plasticity in plant hydraulic architecture in response to supplemental moisture. Ann. Bot. 2012, 109, 1091-1100. [CrossRef] [PubMed]

14. Dee, J.R.; Palmer, M.W. Application of herb chronology: annual fertilization and climate reveal annual ring signatures within the roots of US tallgrass prairie plants. Botany 2016, 94, 277-288. [CrossRef]

15. Dee, J.R.; Palmer, M.W. Annual rings of perennial forbs and mature oaks show similar effects of climate but inconsistent responses to fire in the North American prairie-forest ecotone. Can. J. Forest Res. 2017, 47, 716-726. [CrossRef]

16. Stojnic, S.; Sass-Klaassen, U.; Orlovic, S.; Matovic, B.; Eilmann, B. Plastic growth response of European beech provenances to dry site conditions. Iawa. J. 2013, 34, 475-484. [CrossRef]

17. Brunner, I.; Herzog, C.; Dawes, M.A.; Arend, M.; Sperisen, C. How tree roots respond to drought. Front Plant Sci. 2015, 6, 547. [CrossRef] [PubMed]

18. ERA 5. 2018. Available online: https://confluence.ecmwf.int//display/CKB/What+is+ERA5 (accessed on 16 September 2018).

19. Opština Prokuplje. Available online: https://prokuplje.org.rs/planiranje-i-izgradnja/ (accessed on 30 April 2018).

20. Opština Merošina. Available online: http://www.merosina.org.rs/cir/Planska\%20dokumenta (accessed on 30 April 2018).

21. Zorić, L.; Ljubojević, M.; Merkulov, L.; Luković, J.; Ognjanov, V. Anatomical characteristics of cherry rootstocks as possible preselecting tools for prediction of tree vigor. J. Plant Growth Regul. 2012, 31, 320-331. [CrossRef]

22. Waisel, Y.; Eshel, A.; Kafkafi, U. Plant Roots: The Hidden Half; Marcel Dekker, Inc.: New York, NY, USA, 1996; p. 1002.

23. Wasson, A.P.; Richards, R.A.; Chatrath, R.; Misra, S.C.; Prasad, S.V.; Rebetzke, G.J.; Kirkegaard, J.A.; Christopher, J.; Watt, M. Traits and selection strategies to improve root systems and water uptake in water-limited wheat crops. J. Exp. Bot. 2012, 63, 3485-3498. [CrossRef] [PubMed]

24. Treder, W.; Konopacki, P. Impact of quantity and intensity of rainfall on soil water content in an orchard located in the central part of Poland. J. Water Land Dev. 1999, 3, 47-58.

25. Worbes, M. How to measure growth dynamics in tropical trees a review. Iawa. J. 1995, 16, 337-351. [CrossRef]

26. Worbes, M. Annual growth rings, rainfall-dependent growth and long-term growth patterns of tropical trees from the Caparo Forest Reserve in Venezuela. J. Ecol. 1999, 87, 391-403. [CrossRef] 
27. Menezes, M.; Berger, U.; Worbes, M. Annual growth rings and long-term growth patterns of mangrove trees from the Bragança peninsula, North Brazil. Wetl. Ecol. Manag. 2003, 11, 233-242. [CrossRef]

28. Keserović, Z.; Magazin, N.; Milić, B.; Dorić, M. The ecology of fruit species. In Fruit Science and Viticulture (Part Fruit Science); Keserović, Z., Magazin, N., Milić, B., Dorić, M., Eds.; University of Novi Sad, Faculty of Agriculture, Feljton: Novi Sad, Serbia, 2016; p. 58, ISBN 978-86-7520-370-4. (In Serbian)

29. Janjić, V.; Olar, O. Fertigation of stone trees. In Irrigation and Fertilization of Orchards, Vineyards and Gardens; Janjić, V., Olar, O., Eds.; Nolit: Belgrade, Serbia, 1992; p. 71, ISBN 86-19-01914-7. (In Serbian)

30. Arend, M.; Fromm, J. Seasonal change in the drought response of wood cell development in poplar. Tree Physiol. 2007, 27, 985-992. [CrossRef] [PubMed]

31. Hrotkó, K.; Rozpara, E. Rootstocks and Improvement. In Cherries: Botany, Production and Uses; Quero-García, J., Iezzoni, A., Pulawska, J., Lang, G.A., Eds.; CABI: Boston, MA, USA, 2017; pp. 117-139.

32. Singh, A.; Shamim, M.; Singh, K.N. Genotypic variation in root anatomy, starch accumulation, and protein induction in upland rice (Oryza sativa) varieties under water stress. Agr. Res. 2013, 2, 24-30. [CrossRef]

33. Eilmann, B.; Zweifel, R.; Buchmann, N.; Fonti, P.; Rigling, A. Drought-induced adaptation of the xylem in Scots pine and pubescent oak. Tree Physiol. 2009, 29, 1011-1020. [CrossRef] [PubMed]

34. Tyree, M.T.; Ewers, F.W. The hydraulic architecture of trees and other woody plants. New Phytol. 1991, 119, 345-360. [CrossRef]

35. Tombesi, S.; Johnson, R.S.; Day, K.R.; DeJong, T.M. Relationships between xylem vessel characteristics, calculated axial hydraulic conductance and size-controlling capacity of peach rootstocks. Ann. Bot. 2009, 105, 327-331. [CrossRef] [PubMed]

36. Sperry, J.S.; Saliendra, N.Z. Intra- and inter-plant variation in xylem cavitation in Betula occidentalis. Plant Cell Environ. 1994, 17, 1233-1241. [CrossRef]

37. Maherali, H.; DeLucia, E.H. Xylem conductivity and vulnerability to cavitation of ponderosa pine growing in contrasting climates. Tree Physiol. 2000, 20, 859-867. [CrossRef] [PubMed]

(C) 2018 by the authors. Licensee MDPI, Basel, Switzerland. This article is an open access article distributed under the terms and conditions of the Creative Commons Attribution (CC BY) license (http:/ / creativecommons.org/licenses/by/4.0/). 